\title{
Nutrition and Crohn's disease: An overview
}

\author{
CÓ'MORÁIN, MD, MSC, FRCPC
}

\begin{abstract}
Malnutrition is common in Crohn's disease. Nutrition can be improved in patients with Crohn's disease by total parenteral nutrition (TPN) or enteral nutrition. TPN induces long term remission in over $50 \%$ of patients with Crohn's disease. Enteral nutrition is as effective, more economical and less hazardous than TPN. Enteral nutrition can be given as a polymeric or elemental diet. Polymeric diets can be helpful by improving patient nutritional and clinical status. Elemental diets have other advantages in that clinical improvement is not only symptomatic. A controlled trial suggests it to be more effective than polymeric diets in acute Crohn's disease. Four controlled studies have shown elemental diets to be as effective as steroids in acute Crohn's disease. How an elemental diet achieves this result is conjectural, but it is unlikely that its action is solely nutritional, as the patient improves before nutritional parameters improve. Elemental diets contain glutamine and arginine, which have a direct effect on intestinal mucosa and improve immune function. Patients with active Crohn's disease have increased intestinal permeability; treatment with an elemental diet improves the permeability defect. Can J Gastroenterol 1990; 4(7):400-403
\end{abstract}

Key Words: Crohn's disease, Enteral nutrition, Nutrition, Review, Total parenteral nutrition

\section{Nutrition et maladie de Crohn: Vue d'ensemble}

RESUME: La malnutrition est commune dans la maladie de Crohn. L'état nutritionnel peut toutefois être amélioré par la nutrition parentérale totale (NPT) ou la nutrition entérale. La NPT entraîne des rémissions prolongées chez plus de la moitié des patients porteurs de maladie de Crohn. La nutrition entérale est tout aussi efficace, plus économique et moins risquée que la NPT. Elle peut être administrée sous forme de régime polymérique ou élémentaire. Les régimes polymériques peuvent aider à améliorer l'état nutritionnel et clinique des patients. Les régimes élémentaires présentent d'autres avantages, l'amélioration clinique n'étant pas seulement symptomatique. Un essai contrôlé suggère que les régimes élémentaires seraient plus efficaces que les régimes polymériques dans la maladie de Crohn active. Quatre études contrôlées démontrent que les régimes élémentaires sont aussi efficaces que les stéroïdes dans la maladie de Crohn aiguë. On ne s'explique pas encore ce résultat, mais il est peu probable qu'il soit seulement attribuable aux effets nutritionnels vu que le patient s'améliore avant les paramètres nutritionnels. Les régimes élémentaires contiennent de la glutamine et de l'arginine, lesquelles agissent directement sur la muqueuse de l'intestin et améliore la fonction immunitaire. On constate une perméabilité intestinale accrue chez les patients porteurs de maladie de Crohn active, or le régime élémentaire corrige ces troubles de perméabilité.

Division of Gastroenterology, Meath/Adelaide Hospitals, Dublin, Ireland

Correspondence and reprints: Dr C ÓMoráin, Division of Gastroenterology, Meath/Adelaide Hospitals, Dublin 8, Ireland
$\mathrm{P}$ ATIENTS WITH CROHN'S DISEASE are often in a negative nitrogen balance. The cause of this negative balance is multifactorial and includes reduced food intake, malabsorption due to extensive disease or previous surgery, protein-losing enteropathy and drug nutrient interaction. Sulphasalazine inhibits folate absorption and steroids are catabolic and decrease calcium ab. sorption. Patients who have an abscess or sepsis will have increased energy requirements.

In active Crohn's disease protein malnutrition is common. In one series, approximately one-third of patients were $80 \%$ of ideal body weight (1). Methods used to improve nutrition in Crohn's disease are total parenteral nutrition (TPN) and enteral nutrition.

\section{TPN IN CROHN'S DISEASE}

TPN is effective in inducing remis. sion in some patients with Crohn's dis. ease. Matuchansky (2) reviewed the published studies of TPN in Crohn's disease and noted that $80 \%$ went into remission in the short term and $60 \%$ remained in remission at one year, However, there have been no control. led trials to show that TPN can achieve this result. Long term TPN therapy has been successful in closing fistulas in patients with Crohn's disease, and the most common indication for home TPN is Crohn's disease. In a controlled trial, TPN as adjunctive treatment did not benefit patients with ulcerative colitis (3).

Patients undergoing bowel resection for small bowel Crohn's disease who

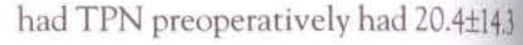


$\mathrm{cm}$ less bowel resected compared to a historical cohort group operated on by the same surgical team. Patients who had a right-sided hemicolectomy with preoperative TPN had $11.2 \pm 4.2 \mathrm{~cm}$ less small bowel resected than the nonTPN group. For large bowel surgery there was no difference in the length of bowel resected. The total hospital stay was 10 days longer for those receiving TPN (4).

Shiloni and colleagues (5) presented a retrospective analysis of 49 patients with severe refractory Crohn's disease who were treated with TPN over an eight year period. Forty-five per cent of the patients treated did not require an operation. However, 50\% required surgery within two years after TPN was discontinued, while only $25 \%$ of those operated on immediately required additional surgery during the follow-up period of 3.5 years. TPN is expensive and has substantial mechanical and metabolic side effects, especially in inexperienced hands. Nevertheless, TPN can induce remission in Crohn's disease by improving the patient's nutritional status and perhaps by allowing the bowel to rest while supplying the patient with adequate calories and removing allergenic stimuli. Greenberg and colleagues (6) have shown in a prospective, two-centre, controlled trial, with 51 patients randomized to either TPN ( $n=17)$, enteral nutrition $(n=19)$ or peripheral enteral nutrition $(n=15)$, that there was no difference in the number of remissions achieved at one year $(42,52$ and $56 \%$, respectively). They concluded that bowel rest was not the mechanism of action of enteral nutrition.

\section{ENTERAL NUTRITION IN CROHN'S DISEASE}

Improved nutrition can be achieved more economically with enteral nutrition. Harries and colleagues (7) have shown that improving nutrition enterally can have a beneficial effect on disease activity. In a controlled crossover trial in which the diet of 28 patients with Crohn's disease was supplemented for two months with 2000 to $3000 \mathrm{kcal}$ per day using a whole protein, low residue, liquid diet, the patients' nutritional parameters (as assessed by anthropometric measurement, serum proteins, creatinine, height index and circulating lymphocytes) were all increased, and serum orosomucoid levels fell while the patients were on liquid diet supplementation. Therefore there may be a 'cause and effect' relationship between nutritional and clinical status.

Nutritional treatment with an oligopeptide diet has been compared to drug therapy with steroids and sulphasalazine in a large, multicentre, prospective, controlled trial involving over 100 patients. The drug treatment group fared better in the number of remissions induced than the diettreated group (8).

\section{ELEMENTAL VERSUS POLYMERIC DIET IN CROHN'S DISEASE}

An elemental diet means food given in its simplest formulation: protein as amino acids, carbohydrate as glucose and fat as short chain triglycerides. An elemental diet reduces pancreatic, biliary and intestinal secretions, is absorbed in the upper intestine, is nonallergenic and could be more effective than a polymeric diet in the treatment of Crohn's disease. An elemental diet has been compared to a polymeric diet in the treatment of acute Crohn's disease in three recent controlled trials (9-11). In one study, 14 patients were allocated randomly to receive $2.4 \mathrm{~L}$ per day for 28 days of an elemental or polymeric diet via a nasogastric tube. Disease activity was assessed by clinical score, $\mathrm{C}$ reactive protein, erythrocyte sedimentation rate and indium leukocyte scan. Gastrointestinal protein loss was similar for both groups, but the post trial clinical score was significantly better for the polymeric diet-treated group. However, three of the elemental diettreated patients failed to complete treatment. Of the 14 patients, only two had small bowel disease.

In another controlled crossover study, 24 patients with active Crohn's disease were randomized to oral elemental or polymeric diets (11). Both diets were effective in inducing remission. None of the patients enrolled had small bowel disease. Undoubtedly, improving patient nutrition improves general well-being and can improve immunological function, but whether nutrition has a more fundamental role in Crohn's disease is not certain.

In another controlled trial, 30 patients with active Crohn's disease who would otherwise have been treated with steroids were randomized to receive an elemental or polymeric diet (11). Assessment on days 10 and 28 showed that clinical remission occurred in five of 14 patients $(36 \%)$ on the polymeric diet compared with 12 of 16 patients $(75 \%)$ assigned to the elemental diet. From this study it can be concluded that a polymeric diet does not seem to be as effective as elemental diets in the treatment of patients with Crohn's disease.

\section{ELEMENTAL DIET VERSUS STEROIDS IN CROHN'S DISEASE}

Corticosteroids are the most effective treatment available for the treatment of Crohn's disease. In a prospective, controlled study, 21 patients with active Crohn's disease, previously untreated, who required hospitalization because of their symptoms, were assigned to receive either steroids at a dosage of 0.5 to $0.75 \mathrm{mg} / \mathrm{kg}$ body weight for four weeks, or an elemental diet as the sole form of treatment. Assessment at four and 12 weeks showed that patients treated with an elemental diet improved as much as steroid-treated patients by some criteria, and more by others such as albumin, which is considered to be a reliable index of disease activity. Mean hospital stay was 11 days for both groups, At a three month follow-up examination none of the diet-treated patients required specific treatment, whereas those in the steroid group were taking 10 to $20 \mathrm{mg}$ prednisolone per day (12). Sanderson and colleagues (13) carried out a similar study in 16 pediatric patients with small bowel Crohn's disease and concluded that an elemental diet was as effective as steroids in the treatment of acute disease.

Saverymuttu and colleagues 
conducted a controlled trial of 37 patients with moderately active Crohn's disease, randomly assigning them to either a regimen of elemental diet with nonabsorbable antibiotics, or steroids. Both groups improved clinically with a comparative fall in the Crohn's disease activity index.

Hunt and colleagues (15), in a three-centre, controlled study of 29 patients with active Crohn's disease who were randomized to either an elemental diet or steroids at a dosage of 0.5 to $0.75 \mathrm{mg} / \mathrm{kg}$ body weight, also found an elemental diet to be as effective as steroids and superior to a polymeric diet in inducing remission in Crohn's disease.

\section{MODE OF ACTION OF AN ELEMENTAL DIET}

How an elemental diet improves Crohn's disease is uncertain. It is unlikely to do this by nutrition alone, as patients improve before any improvement occurs in their nutritional parameters. Patients with small bowel Crohn's disease appear to do best in terms of long term relapse with an elementaldiet (16). The small bowel is dependent on luminal substrates for its nutrition. It is important to note that an enteral elemental diet contains glutamine and arginine. Glutamine is the major fuel for the small intestine's own energy needs (17). In a patient with Crohn's disease, gut requirements for glutamine may be greater than normal. Steroids have been shown to stimulate glutamine release from muscle and to increase intestinal consumption of glutamine (18). Glutamine affects enterocyte function directly and stimulates tropic gut hormones.

Arginine enhances immune func-

\section{REFERENCES}

1. Rosenberg IH, Bengoa JM, Sitrin MD. Nutritional aspects of inflammatory bowel disease. Annu Rev Nutr 1985;5:463-84.

2. Matuchansky C. Parenteral nutrition in inflammatory bowel disease. Gut 1986;27(Suppl 1):81-4.

3. Dickinson RJ, Ashton MG, Axon ATR, Smith RC, Yeung CK, Hill GL. Controlled trial of intravenous hyperalimentation and total bowel rest as an tion and promotes nitrogen retention in animal models. In patients undergoing surgery for cancer, arginine had a beneficial effect on the immune system distinct from its nutritional effect (19).

An elemental diet could benefit patients with Crohn's by inducing a critical change in bowel flora. Kane and Neal (20) proposed total gut irrigation with antibiotic sterilization as an effective treatment for Crohn's disease. The author has studied the fecal flora of patients before and after treatment with an elemental diet and found no significant change in the total number of organisms nor any significant alteration in coliforms or enteroccocci (21). This is a relatively insensitive method for detecting subtle changes in bowel flora. Wellmann and colleagues (22) described a potential role for absorbed enterotoxin contributing to the systemic symptoms of Crohn's disease. In a controlled study comparing two groups of patients, both received TPN and steroids and, if appropriate, sulphasalazine and metronidazole. One group also randomly received whole gut lavage with $18 \mathrm{~L}$ saline given over $2 \mathrm{~h}$ on two occasions during the first week. At the end of each lavage period, $4 \mathrm{~g}$ 5 -aminosalicylic acid were given. The lavage group had a significantly more rapid fall in Crohn's disease activity index and circulating endotoxin, and a shorter stay in hospital. It is possible that an elemental diet could induce improvement by reducing circulating endotoxins. The altered immune function observed in Crohn's disease could be secondary to an abnormality of mucosal permeability that allows microbial or dietary antigens access to the mucosa. Once absorbed, these antigens could

adjunct to the routine therapy of acute colitis. Gastroenterology 1980;79:1199. 204.

4. Lashner BA, Evans AA, Hanauer SB. Preoperative total parenteral nutrition for bowel resection in Crohn's disease. Dig Dis Sci 1989;34:741-6.

5. Shiloni E, Coronado E, Freund HR. Role of total parenteral nutrition in the treatment of Crohn's disease. Am J Surg 1989;157:180-5.

6. Greenberg GR, Fleming CR, cause chronic inflammation. Phospholipase activity is increased in active Crohn's disease. Lysolecithin, a product of this activity, could cause tissue damage and increase intestinal permeability (23). The author has shown that chromium-labelled EDTA is a simple, safe, inexpensive, noninvasive screening test for detection of Crohn's disease, particularly of the small bowel. The author has also found it useful to monitor disease activity $(24,25)$. The increased urinary excretion after oral administration of EDTA suggests that patients with Crohn's disease have increased mucosal permeability. A study to examine whether treatment of acute Crohn's disease with an elemental diet improved intestinal permeability and inflammation (as assessed by EDTA and lactulose/rhamnose permeability) has shown a significant decrease in the urinary excretion of these probes, indicating that treatment is not solely symptomatic $(26,27)$. Hollander $(28)$ reported a high prevalence of increased permeability to polyethylene glycol 400 in apparently unaffected first de. gree relatives of patients with Crohn's disease, suggesting that increased permeability may be a primary abnor. mality in Crohn's disease (28). Similar studies using lactulose/rhamnose and chromium-labelled EDTA have been normal, perhaps reflecting the different permeation pathways that these probes used $(29,30)$.

Elemental diets are useful and free from side effects in inducing remission in Crohn's disease. They have effects beyond nutrition. More effort should be made to discover the exact mechanism of how elemental diets work and to find the optimum period required to induce remission.

Jeejeebhoy KN, Rosenberg IH, Sales D, Tremaine WJ. Controlled trial of bowel rest and nutritional support in the management of Crohn's disease. Gut 1988;29:1309-15.

7. Harries AD, Jones LA, Denis V, Fifield R, Heatley RV, Newcombe RG. Controlled trial of supplemented oral nutrition in Crohn's disease. Lancet 1983; i:887-90.

8. Lochs H, Steinhardt HJ, Klaus-Wenz B, Bauer P, Malchow H. Enteral nutri- 
tion versus drug treatment for the acute phase of Crohn's disease of study IV. Gastroenterology 1988;94:A267. (Abst)

9. Park RHR, Galloway A, Danesh BJZ, Russell RI. Double-blind trial comparing elemental and polymeric diet as primary treatment for active Crohn's disease. Gut 1989;30: A1453-4. (Abst)

10. Raouf AH, Hildreg V, Dania J, et al. Enteral feeding as sole therapy for Crohn's disease, a controlled trial of whole protein versus amino acid based feed. Gut. (In press)

11. Giaffer MH, North G, Holdsworth CD. Controlled trial of polymeric versus elemental diet in treatment of active Crohn's disease. Lancet 1990;i:816-9.

12. Ó'Moráin C, Segal AW, Levi AI. Elemental diet as primary treatment of acute Crohn's disease: A controlled trial. Br Med J 1984;288:1859-62.

13. Sanderson IR, Udeen S, Davies PS, Savage MO, Walker-Smith JA. Remission induced by an elemental diet in small bowel Crohn's disease. Arch Dis Child 1987;62:123-7.

14. Saverymuttu S, Hodgson HJ, Chadwick VS. Controlled trial comparing prednisolone with an elemental plus non-absorbable antibiotics in active Crohn's disease. Gut 1985;26:994-8.

15. Hunt JB, Payse James JJ, Palmer KR, et al. A randomized controlled trial of elemental diet and prednisolone as primary therapy in acute exacerbations of Crohn's disease. Gastroenterology 1989;96:A224. (Abst)

16. Teahon K, Bjarnason I, Levi AJ. Elemental diets in the management of Crohn's disease - A 10-year review. Gastroenterology 1988;94:A457.

17. Souba WW, Smith RJ, Wilmore DW. The gut as a nitrogen processing organ in the metabolic response to critical illness. Nutr Supp Serv 1988;8:15-22.

18. Souba WW, Smith RJ, Wilmore DW. Effects of glucocorticoids on glutamine metabolism in organs. Metabolism 1985;34:450-6.

19. Daly JM, Reynolds J, Thom A, et al. Immune and metabolic effects of arginine in the surgical patient. Ann Surg 1988;208:512-23.

20. Kane SP, Neale G. Ileocolitis responding to bowel sterilization. Proc R Soc Med 1976;69:266.

21. O'Morain C. Crohn's Disease, Treatment and Pathogenesis. Boca Raton: CRC Press, 1987:240.

22. Wellmann W, Fink PC, Benner F, Schmidt FW. Endotoxaemia in active Crohn's disease. Treatment with whole gut irrigation and 5-aminosalicylic acid. Gut 1986;27:814-20.

23. Bolin T, Heuman R, Sjodahl R, Tagesson C. Decreased lysophospholipase and increased phospholipase $\mathrm{A}_{2}$ activity in ileal mucosa from patients with Crohn's disease. Digestion 1984:29:55-9
24. Ó’Moráin CA, Abelow AC, Chervu LR, Fleischner GM, Das KM.

Chromium 51-ethylenediaminetetra acetate test: $A$ useful test in the assessment of inflammatory bowel disease. J Lab Clin Med 1986;108:430-5.

25. Bjarnson I, O'Moráin C, Levi AJ. Peters T]. Absorption of 51 chromiumlabelled EDTA in inflammatory bowel disease, Gastroenterology 1983;85:318. 22.

26. Teahon K, Bjarnason I, Levi AJ. The effect of elemental diet on intestinal permeability and inflammation in Crohn's disease. Gastroenterology. (In press)

27. Sanderson IR, Boulton P, Menzie BI, Waker-Smith JA. Improvement of abnormal lactulose/rhamnose permeability in active Crohn's disease of the small bowel by an elemental diet. Gut 1987;28:1073-6.

28. Hollander D. Crohn's disease in a permeability disorder of the tight junctions. Gut 1988;29:1621-4.

29. Katz KO, Hollander D, Vadheim CM, et al. Intestinal permeability of inpatients with Crohn's disease and their healthy relatives. Gastroenterology 1989;97:927-31.

30. Ainswood M, Eriysen J, WaeverRasmussen J, Schafflitzky de Muckaoell $\mathrm{OB}$, et al. Intestinal permeability of ${ }^{51} \mathrm{Cr}$ labelled ethylenediaminetetra acid in patients with Crohn's disease and their healthy relatives. Scand J Gastroenterol 1989;24:993-8. 


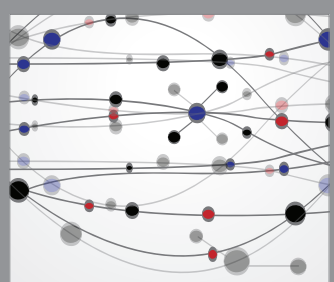

The Scientific World Journal
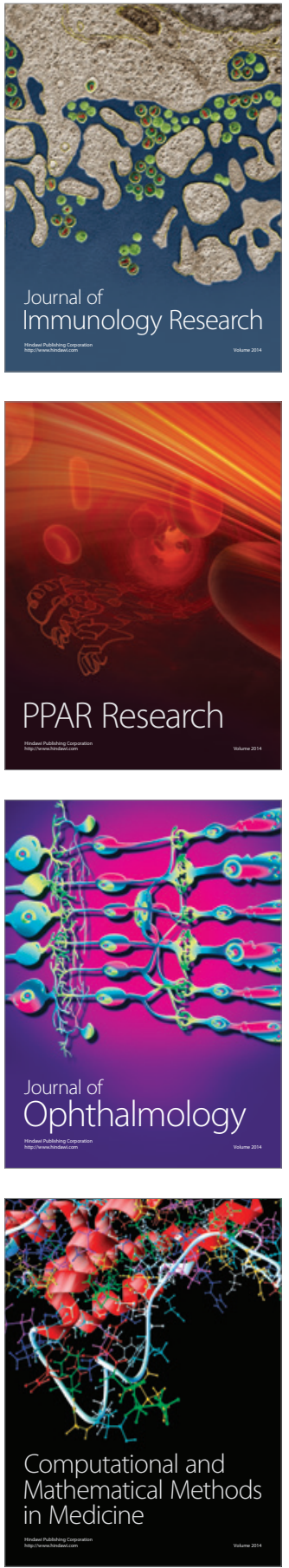

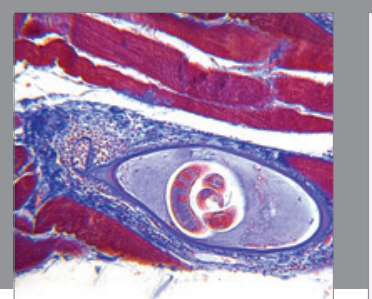

Gastroenterology Research and Practice

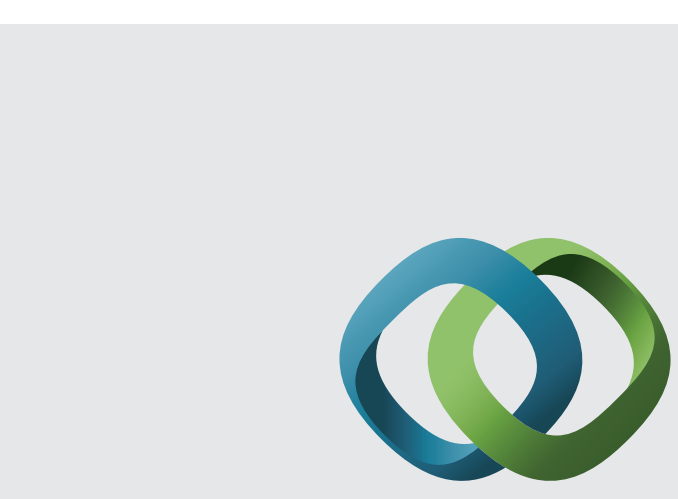

\section{Hindawi}

Submit your manuscripts at

http://www.hindawi.com
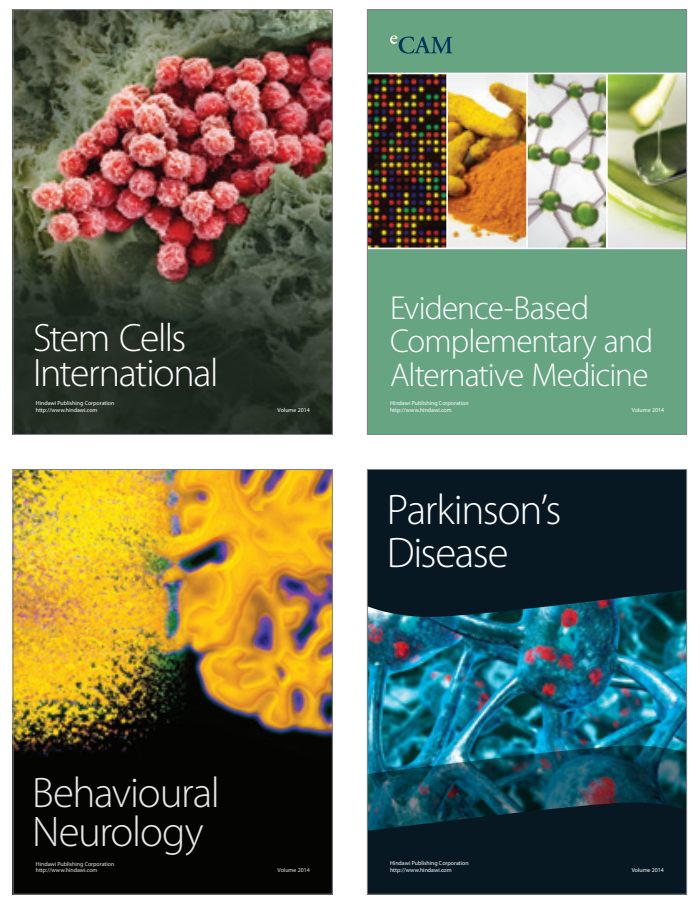
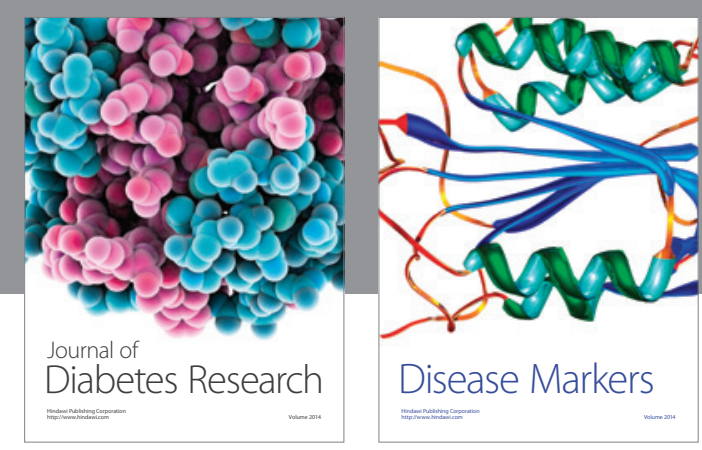

Disease Markers
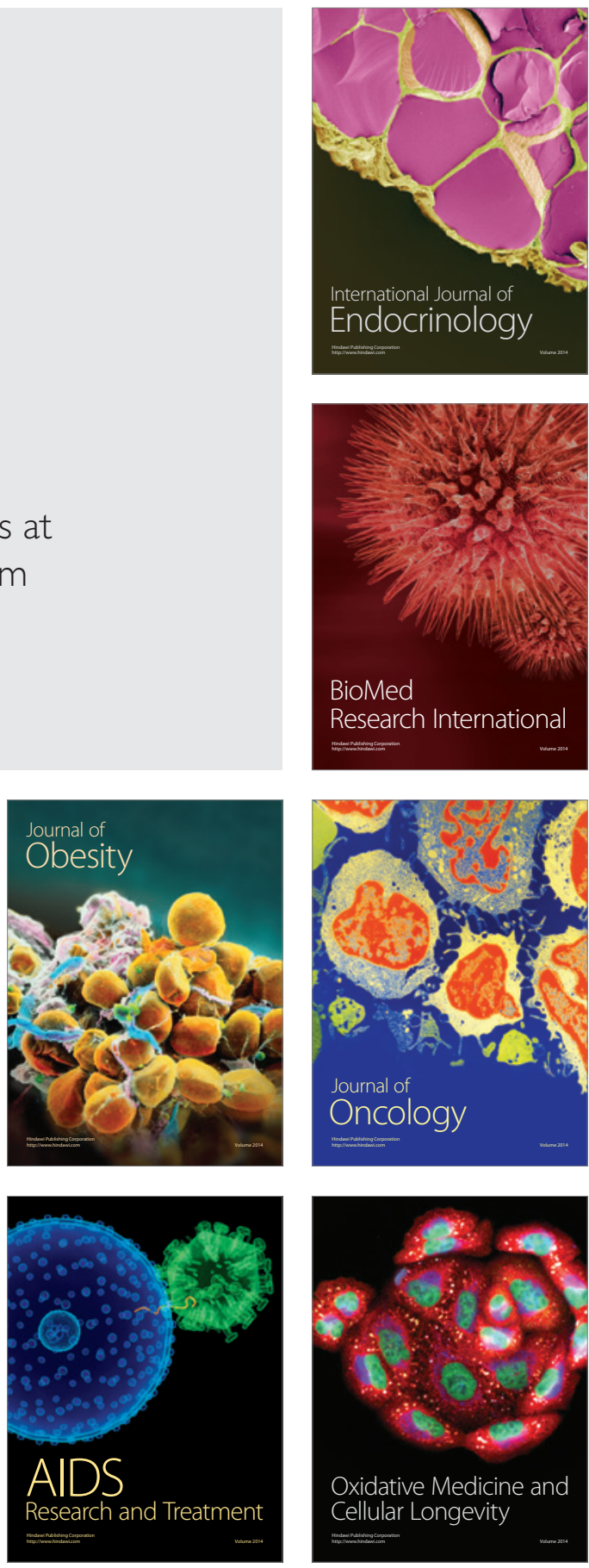